\title{
Has the Amplitude of Business Cycles Deepened in the Post-World War II Era? A Variance Analysis of Thirty-Five Countries
}

\author{
Nozar Hashemzadeh \\ Radford University \\ Daniel Farhat \\ Radford University
}

"The capitalist's system is a sorcerer, who is no longer able to control the powers of the nether world whom he has called up by his spells." Marx and Engels

According to Karl Marx, business cycles in capitalist economies should increase in amplitude over time. In this hypothesis, income and wealth inequality should increase within a capitalist system, resulting in increased economic instability. Thanks to Keynesian policy recommendations, governments and central banks have discovered policy options for correcting downturns in the economy. However, if Marx is correct, policy makers will face business cycle movements ever-increasing in severity. In this article, we review Marx's hypothesis in the literature. Further, we briefly look at recent (post-war) data to see if empirical evidence supports Marx's original claim.

Keywords: business cycle volatility, income and wealth inequality, economic instability.

\section{INTRODUCTION}

In the theory of capitalist development, Paul Sweezy (1942, p. 352-63) postulated that Karl Marx's hypothesis of the increasing amplitude of the business cycle was both incorrect and old fashioned. Marx had suggested that in contemporary societies (China included), production and employment are closely tied to aggregate demand by consumers, businesses, government and international demand for domestically produced goods and services. Marx's hypothesis of worsening recessions under capitalism is based on the relationship of "a gigantic means of production and exchange" and the inability of the working class to absorb surplus output due to lack of adequate wages and income (Marx 1963, p.208210). Years later, the Marxian analysis of capitalist systems served to provide the foundation for Keynesian macroeconomic theory and expounded the underlying conditions for recurrent boom and bust cycles in modern capitalist societies.

Marx's hypothesis about the increasing depth of business cycles depends on several economic and social factors: excessive income inequality, past and present colonialism, inept government policy, extensive corruption and other unanticipated social and natural disorders that add fuel to business cycle severity. The role of inequality is of particular interest. Economists Jason Furman (Harvard) and Joseph E. Stiglitz (Columbia) offer a persuading argument "that an increase in inequality may increase the 
equilibrium level of unemployment and may lead to a higher level of (cyclical) unemployment under capitalism" (1998, p.254). This interpretation is consistent with the Marxian view of the future of capitalism.

In this article, we explore the connection between income inequality and Marx's hypothesis regarding increasing business cycle volatility. We review trends in the literature and in the data for select economies. We show an increased concern by researchers over inequality during the business cycle (as it relates to the causes and consequences of recessions). We look at the Great Depression and the Great Recession as significant turning points in the U.S. economy, where shifts in inequality occurred (both before and after these large downturns). When we look at current empirical evidence, we find mixed support for Marx's hypothesis. We end the discussion with perspectives on future research.

\section{MARX'S HYPOTHESIS IN THE LITERATURE}

\section{Worsening Income Inequality}

Thomas Piketty (2014) notes that income inequality in the U.S. has been increasing since 1980 due to the exodus of means of production, including physical capital, to the top decile of the population. This phenomenon should be of great concern to policy makers. Thomas Piketty and Gabriel Zucman (2014) predict that income and wealth equality and economic growth will decrease dramatically in the twentyfirst century. They propose that further accumulation of capital (by the wealthy) will slow down economic growth and further contribute to the impoverishment of the masses. These predictions are broadly based on the Harrod-Domar Economic Growth Model which foresees the gradual substitution of capital for labor (robotization), an exacerbated unemployment rate for the manufacturing labor and an accelerated future decline in the labor share of aggregate income. It is, therefore, reasonable to expect income and wealth inequality to continue to worsen, social safety nets to eventually become inadequate, unemployment compensation reserves to become underfunded and unemployment to rise. These can drive an economy into a recession, if not a depression.

Noted author and labor economist Sam Pizzigati (2017) of the Institute for Policy Studies faults the income and wealth inequality to be responsible for the depth of the Great Recession (Feb. 18, 2017). Not surprisingly, abundant current and historical evidence from both contiguous and non-contiguous economies in all continents suggest that high levels of income inequality have and will cause serious political, social and economic upheavals. In the United States, for instance, income inequality reached high levels prior to the Great Depression and the Great Recession (U.S. Congress Joint Economic Committee, September 2010, p.2).

As Michele Berger (2016), of the University of Pennsylvania explains "the Great Recession is the biggest economic downturn since the Great Depression of the 1930s. If you can't make an argument that inequality matters for the severity of this downturn, then it's unlikely to matter much for smaller recessions, or for normal times".

In an empirical study of U.S. household behavior, Hashemzadeh and Farhat (2017) demonstrate that low income strata of the population had much higher marginal propensity to consume (MPC) when compared to the top 25 percentile of the income distribution. Worsening income inequality increases the size of low-income groups (relative to high income groups), which may result in a different impact of a recession on the economy than it would have if the income distribution remained constant. In other words, different income groups have different spending behaviors, and any significant drop in income for the lower middle class will significantly impact consumption and aggregate demand.

This set of research is just a sample illustrating a growing concern over the connection between inequality and business cycles. Keynesian and Marxists economists would generally agree that extensive inequality will, in due time, reduce aggregate consumption, hasten the closure of production units, and accelerate layoffs. The consequences of a deteriorating economy are widespread decrease in wealth and income across all income groups, with some being impacted more than others. In a capitalist system, the profit margin will also play a crucial role in determining the level of employment, investment and 
innovation. The onset of uncertainty and fear drives down returns on physical capital, securities, rental income and other forms of investments (typically held by the richer members of society).

We must distinguish between the impact of a recession and the cause of a recession. While Marx's theory of business cycle volatility emphasizes under-consumption as the major trigger of recessions, other triggers of business cycles could be the onset of the Keynesian animal spirit, such as excess optimism during cyclical expansions and undue pessimism during contractions. Howard Sherman, an acknowledged Marxists authority, appears to support the Keynesian view that depressions result from relatively small drops in "the rate of profit in a short period, not from tiny changes over many decades" (2004, p.1). In addition to drops in profits, other catalysts such 'inventory cycles', the cycle of depreciation and replacement investment, the role of money credit and inflation, the existence of monopolies and trade restrictions are among the many conceivable triggers of recessions. These effects have significant wealth effects when the economy begins to experience gloom and doom. Layoffs result in loss of income thereby impacting consumption and investment spending and the aggregate demand, which subsequently results in more unemployment and inventory pile-ups and a wave of bankruptcies.

\section{Business Cycles in Historical Perspective: The Great Depression and the Great Recession}

Marx's prophecies about the inherent instabilities of capitalism were put to a material test during the Great Depression, and the more recent Great Recession of 2008. In both settings, the share of income claimed by the top percent of the U.S. population approximated about 50 percent of total gross domestic income. By 2008, the wealthiest one percent of the population claimed more than 21 percent of total income while the middle class and the lower strata of the U.S. population suffered from mounting debt, foreclosure and bankruptcy.

National Bureau of Economic Research (NBER, 2019) records confirm that the U.S. economy went through 33 recessions between 1857 and 2019. NBER records highlight the Great Depression as a turning point in American business cycle trends. In the period before the Great Depression, 1857-1927, recessions lasted 20.5 months on average and the expansionary periods between recessions averaging about 46.2 months. By comparison, the Great Depression, which constituted a severe departure from the norm, lasted almost 99 months, from October 1929 through 1938. The causes of the massive contraction in output, investment and employment ('over-production' versus 'under-consumption') are still being debated in the macroeconomics literature (Sewell, 2012).

Milton Friedman and Anna Jacobson Schwartz (1963) attributed the Great Depression to detrimental contractionary monetary policies by the Federal Reserve Bank resulting in the demise of 7,000 commercial banks in the United States. Bernanke (1995) outlines a host of additional causes, including drops in autonomous consumption, choice of exchange rate regime and operation of the gold standard, the impact of banking panics and the stickiness of nominal wages. While the root causes are open to discussion, the adverse consequences of the Great Depression are well-known: wide-spread loss of wealth, reductions in employment and increases in social instability.

The Great Depression was not limited to the U.S. alone. Severe economic and social impacts on several capitalist and semi-capitalistic nations occurred around the world. The labor markets of the United States, Canada, Germany, the United Kingdom, Norway, Australia and many others were severely affected. According to Galenson and Zelner (1957, p.455), national unemployment rates reached levels as high as $28.1 \%$ in Australia (1932), 26.6\% in Canada (1933), 43.8\% in Germany (1932), 33.4\% in Norway (1933) and 22.1\% in the United Kingdom (1932). Granados and Roux (2009, p.1) place the historical maximum unemployment rate for the United States at 22.9\% in 1932. Prior to the Great Depression, the only downturn that had persisted longer was the recession caused by the Panic of 1873 (65 months, 18731879). This long recession was weaker by far in terms of unemployment, which peaked at $8.25 \%$ (Vernon, 1994). In the post-war years, 1945-2009, recession duration had fallen to an average of 10.83 months while expansion duration had increased to 70.6 months on average. It had seemed that economic policy makers had developed ways to effectively promote economic stability and long-term growth in the latter half of the $20^{\text {th }}$ century. 
The more recent deep recession, commonly referred to as the 'Great Recession' which resulted from unwarrantable expansion in construction and mortgage loans, was also mild by comparison. Although this recession lasted only 18 months, its fiscal impact on the American economy was enormous. A report by the Federal Reserve Bank of St. Louis (2018) documents that the Federal Debt "increased from 62 percent of gross domestic product (GDP) in 2007 to over 100 in 2013". From December 2007 to October 2009, the U.S. unemployment nearly doubled- from 5.1 percent to 10.1 percent. In addition to impacting, output, employment and income, it is estimated that U.S. financial markets and households lost more than 14 trillion dollars in wealth in the course of this recession (Federal Reserve History, December 2017).

Christine Romer who chaired the Council of Economic Advisors during the Obama Administration has theorized that business cycles are not a fact of economic history and "there is no reason why cycles have to occur at all" (Romer, 2008; italics added). Romer theorizes that recessions result from errors in macroeconomic policy decisions. Nevertheless, after narrating the history of business cycles in the United States, Romer paradoxically reaches the conclusion that "business cycles do occur" due to unpredicted instabilities. In fact, Romer admits that the length of recessions has become longer after World War II when compared to similar recessions prior to 1940s (Romer, 1999, p.30). Romer's contention about the reality of business cycles conflicts with documented history of numerous economic collapses since the development of organized economic spheres in cities like Damascus and Aleppo (Syria), Baghdad (Iraq), Jericho (West Bank), Byblos (Lebanon), Fanyu (Egypt), Ray (Iran), Luoyang (China), Timbuktu (Africa), Tenochtitlan (Mexico), Mari (Mesopotamia) and a dozen more economic zones which were prosperous production and trade hubs.

\section{EMPIRICAL ANALYSIS OF INEQUALITY AND BUSINESS CYCLE VOLATILITY}

We turn now to an empirical re-evaluation of business cycle volatility and inequality. The impetus for this research is the occurrence of the Great Recession from 2007-2009. Prior, it had seemed that the 'business cycle problem' was solved by policy. For nearly 25 years prior to 2007, there were only three relatively mild recessions in the U.S. When the Great Recession occurred, the monetary authority was forced to take extreme measures: force interest rates to near zero and explore alternative options (such as quantitative easing). This recession seems to have laid the groundwork of fear and uncertainty which is still apparent in the behavior of monetary authorities in the European Union (EU), Japan, China, the U.S. and elsewhere. We became curious as to how these effects were distributed across the income distribution. During our investigation, we wondered about the connection between income inequality and business cycle volatility (i.e. do very unequal societies have deeper or longer recessions?). When looking at the U.S., it appears that both wealth inequality and income inequality had been on the rise since the mid-1980s prior to the Great Recession. See figure 1, which represents inequality as measured by the share of total pre-tax national income and total net personal wealth going to the richest $10 \%$ of the population (World Inequality Database, 2019). A slight rise in inequality was also apparent just before the Great Depression, but then declined and leveled-off between the 1940s and 1980s (a time when business cycles had become more stable in the U.S.). In an era with multiple fiscal and monetary policy tools to stabilize the economy, focusing on singular events within the U.S. only has limitations. To enrichen our understanding further, we compared inequality and business cycle volatility across multiple economies during the entire post-war era (1950s to 2017). 
FIGURE 1

\section{INEQUALITY IN THE U.S. 1913 - 2014}

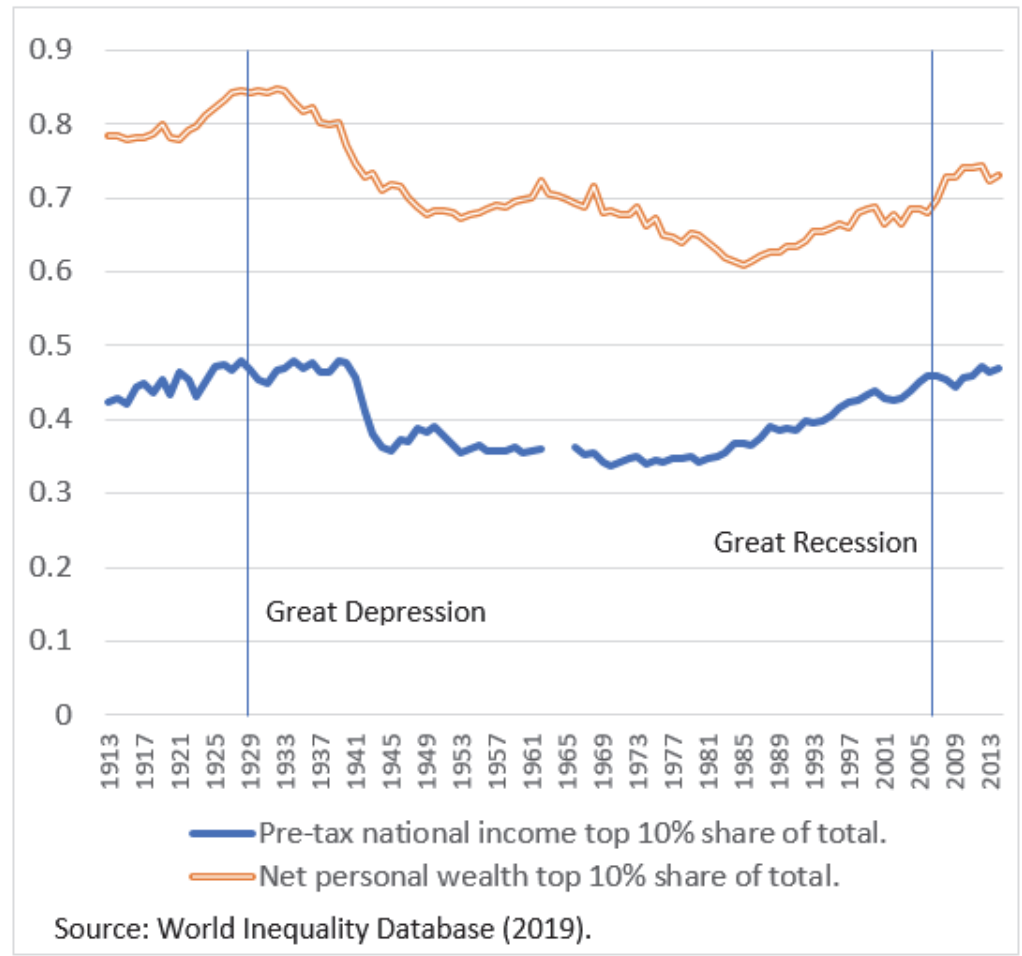

We began with an analysis of business cycle volatility trends. We first extracted real GDP data from the Penn World Tables. All data is annual and measured in millions of 2011 U.S. dollars (at chained PPPs, expenditure approach). The countries included in our analysis are: Argentina, Australia, Austria, Belgium, Brazil, Canada, Denmark, Egypt, Finland, France, Germany, Greece, Hong Kong, Iceland, India, Iran, Ireland, Israel, Italy, Japan, Malaysia, Mexico, Netherlands, New Zealand, Niger, Nigeria, Norway, Portugal, South Africa, South Korea, Spain, Sweden, Switzerland, Turkey, United Kingdom and United States. Data for most countries covers 1950-2017, with some exceptions (Greece: 1951-2017, Hong Kong: 1960-2017, Iran: 1955-2017, Malaysia: 1955-2017, Niger: 1960-2017 and South Korea: 1953-2017).

The following procedure was then followed for each country. We took the natural log of each series $\left(y_{t}\right)$. We then extracted a flexible trend using the Hodrick-Prescott Filter $\left(\bar{y}_{t}\right)$. We computed the cycle component of GDP as the deviation from trend $\left(c_{t}=y_{t}-\bar{y}_{t}\right)$. Because the data is in natural log form, the cycle component can be interpreted as the percent deviation from the flexible trend (when sufficiently small). Next, we divided the data into two samples: pre-1980 and post-1980. For each sample, we computed the variance of the cycle $\left(\sigma_{\text {Pres0 }}^{2}\right.$ and $\left.\sigma_{\text {Post } 80}^{2}\right)$. We then computed an F-statistic as $\mathrm{F}=\sigma_{\text {Post80 }}^{2} /$ $\sigma_{\text {Pres0 }}^{2}$. This F-statistic is associated with the null hypothesis that the volatility of GDP in the pre-1980 sample is no different from that in the post-1980 sample (comparing two sample variances, see Snedecor and Cochran (1989) for a description of this test). If the F-statistic is too large, volatility has increased significantly over time. If the F-statistic is too small, volatility has decreased significantly over time. Using an F-table, we identify an upper critical value and a lower critical value at the $5 \%$ confidence level using the appropriate degrees of freedom.

The F-test shows that we can reject the null hypothesis at the upper critical value for Norway, Nigeria, Argentina, Brazil, Egypt, Ireland, Mexico, Sweden, France and Netherlands. Volatility of the business cycle has increased in these countries. We can reject the null hypothesis at the lower critical values for South Africa, Iran, Australia, Israel and New Zealand. Volatility of the business cycle has 
decreased in these countries. We fail to reject the null hypothesis for the remaining countries, suggesting no substantial changes in volatility over time.

Next, we compare these volatility patterns to trends in inequality. We extracted estimates of the GINI coefficient for each country using data from the World Income Inequality Database (WIID4). This data set contains GINI estimates for each country taken by different organizations at different points. GINI coefficients vary from one (or $100 \%$, perfect inequality) to zero (or $0 \%$, perfect equality). For each country, we did the following. When estimates from multiple organizations occurred in the same year, we took the average to produce a single estimate for that year. We then divided the available data into the two sample periods (pre-1980 and post-1980). Data availability for each country is summarized in table 1 in the appendix below. We took the average of the available data within each sample period. Our findings are summarized in Figure 2 through 4. For the sample used, the value of the GINI coefficient is shown in the left side of Figure 2-4 by a circular symbol. We should note that lower values of the coefficient (extreme left) signify more income equality. Among the countries listed, the citizens of the Scandinavian countries enjoy greater equality. Data for Iceland's GINI coefficient is not available for the pre-1980 period.

Figure 2 shows countries whose business cycles are becoming more volatile. Some of these countries have high GINI coefficients (such as Brazil), while others have low GINI coefficients (such as Norway). The difference between pre- and post-1980 GINI estimates also varies. For many of these countries, the average GINI coefficient is higher in the less-volatile pre-1980 period than it is in the post-1980 period, suggesting more inequality when business cycles are smooth (Argentina is the only exception). This may be due to the growing inequality associated with the expansion phase of the business cycle. As noted by Hahnel and Sherman (1982) and Lear (1992), the gap between what workers earn and what capital owners earn widens as the economy expands, generating less equality. If the countries in this group have longer expansion phases in the smooth pre-1980 period, then we would expect them to have higher GINI coefficients in this period as well.

Figure 3 shows countries with equally-volatile business cycle movements. Some have low inequality (like Austria), while others have high inequality (like Malaysia). For most countries inequality is lower in the post-1980 period. However, there are a few countries where inequality is on the rise (the United Kingdom and Canada).

Figure 4 shows countries whose business cycles are becoming less volatile. Results again are mixed, with some countries having high GINI estimates and other having low GINI estimates. The difference between pre- and post-1980 averages again is mixed, with some countries having more inequality in the less volatile post-1980 period (South Africa, Australia and Israel, once again consistent with Hahnel and Sherman (1982) and Lear (1992)) while the reverse occurs for others (Iran and New Zealand).

What is of note is the degree to which inequality seems to have changed. In the group of countries with equally volatile business cycles (Figure 3), there is rather little change in the average GINI estimate (ranging from approximately +5 to -8 ). In the group of countries with increasing business cycle volatility and decreasing business cycle volatility, more extreme changes in the average GINI coefficient are observed. In the group of countries with increasingly volatile cycles (Figure 2), Sweden, Nigeria, France and the Netherlands all experienced rather sharp falls in the GINI. In Argentina, there was a sharp rise in the GINI. Examples of sharp GINI changes from the group of countries with lowering business cycle volatility can also be identified. New Zealand experiences a sharp fall while South Africa and Israel experience rises.

In the end, many results are mixed. We expected to see a consistent positive correlation between inequality and business cycle volatility: either a higher GINI estimate or an increase in the GINI estimate makes for more volatile business cycles. We only saw this in select economies including Argentina, New Zealand and Iran. Most other countries seem to suggest high or growing inequality during more stable periods which is suggested by other economists. But it is the connection between the magnitude of GINI movements and business cycle volatility that we think is of particular interest. Moving either from high to low volatility or low to high volatility seems to be connected to rather large changes in inequality: 
sometimes for the better, sometimes for the worse, but larger nonetheless. This result can be seen in Figure 5 below.

FIGURE 2

F-TEST AND AVERAGE GINI COEFFICIENTS FOR COUNTRIES WITH BUSINESS CYCLES THAT ARE BECOMING MORE VOLATILE (HIGHER STANDARD DEVIATION IN POST1980 PERIOD COMPARED TO PRE-1980 PERIOD).

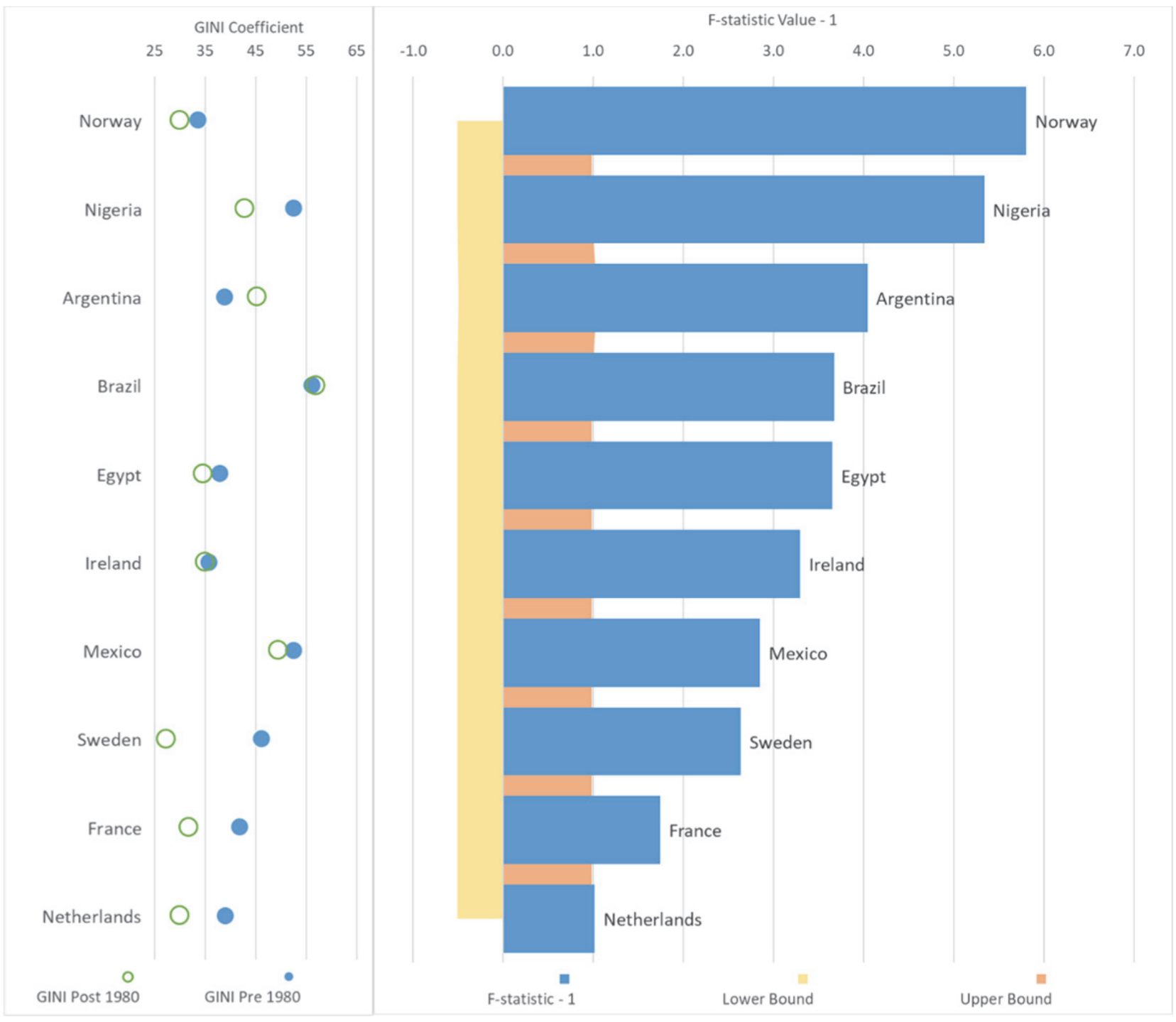


FIGURE 3

F-TEST AND AVERAGE GINI COEFFICIENTS FOR COUNTRIES WITH BUSINESS CYCLES THAT ARE EQUALLY VOLATILE (STANDARD DEVIATION IN POST-1980 PERIOD IS NOT STATISTICALLY DIFFERENT FROM STANDARD DEVIATION IN PRE-1980 PERIOD).

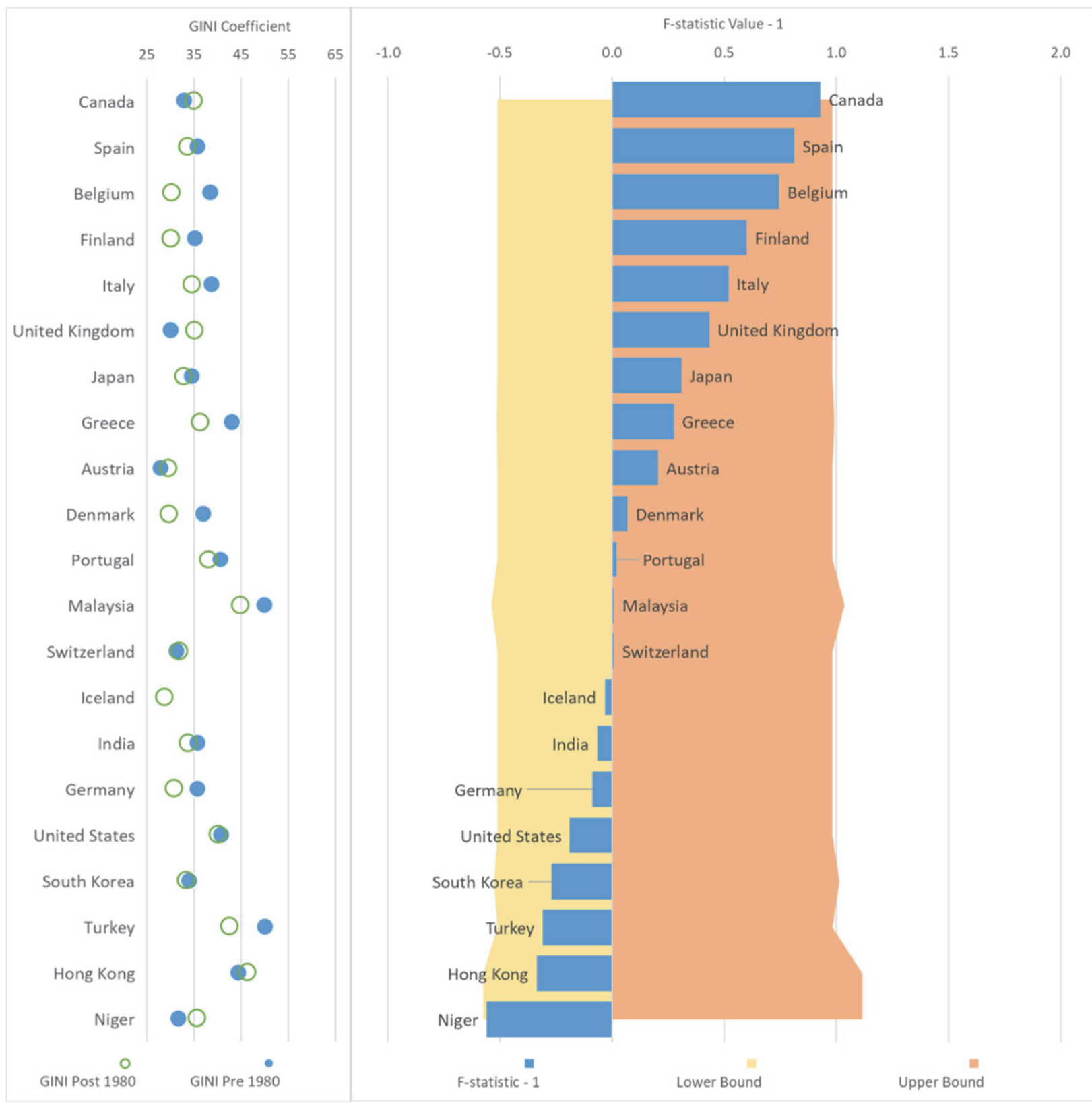


FIGURE 4

F- TEST AND AVERAGE GINI COEFFICIENTS FOR COUNTRIES WITH BUSINESS CYCLES THAT ARE BECOMING LESS VOLATILE (LOWER STANDARD DEVIATION IN POST-1980 PERIOD COMPARED TO PRE-1980 PERIOD).

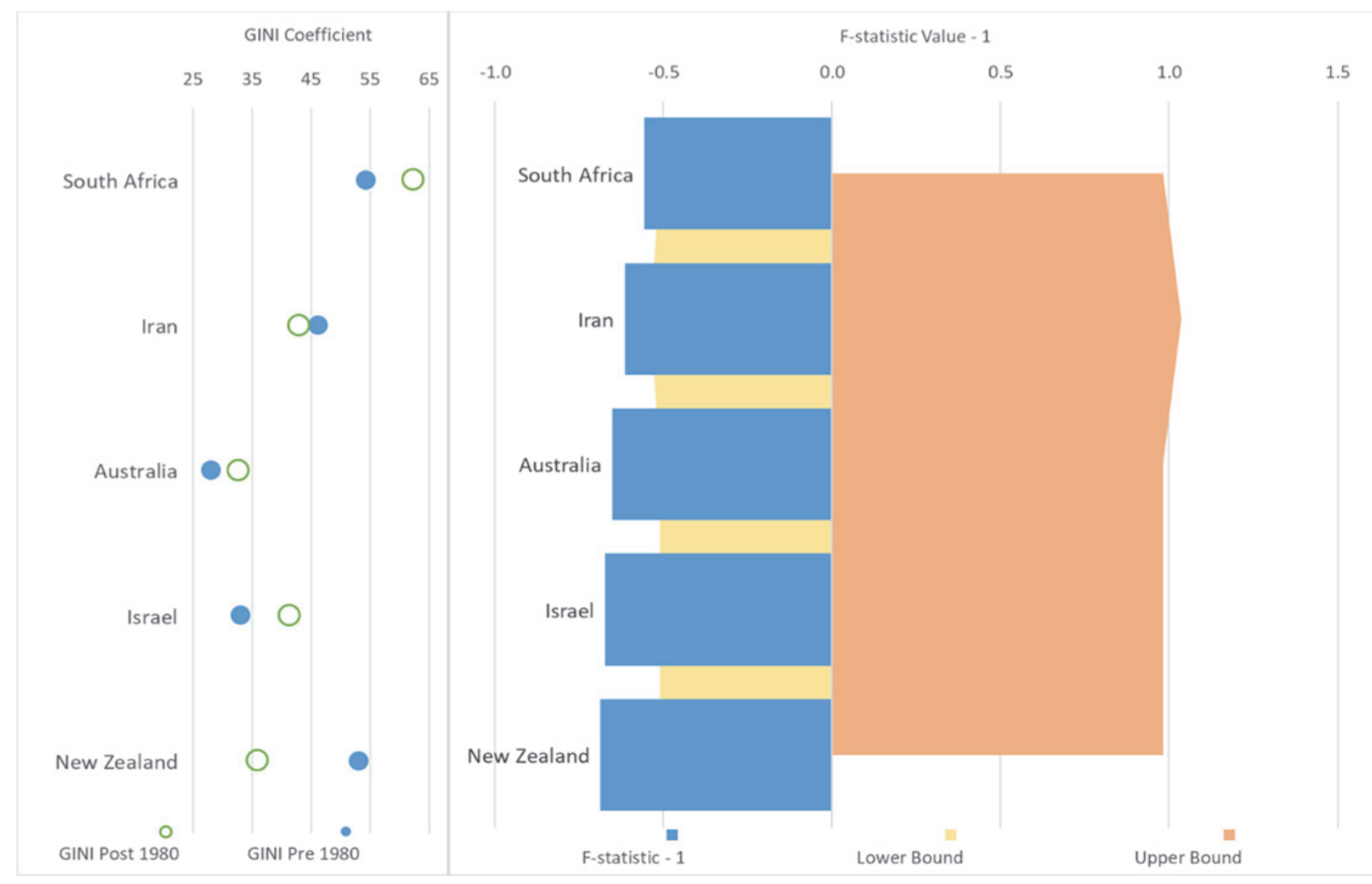

FIGURE 5

PRE-1980 AVERAGE GINI COEFFICIENT VERSUS CHANGE IN AVERAGE GINI COEFFICIENT (POST-1980 AVERAGE GINI MINUS PRE-1980 AVERAGE GINI).

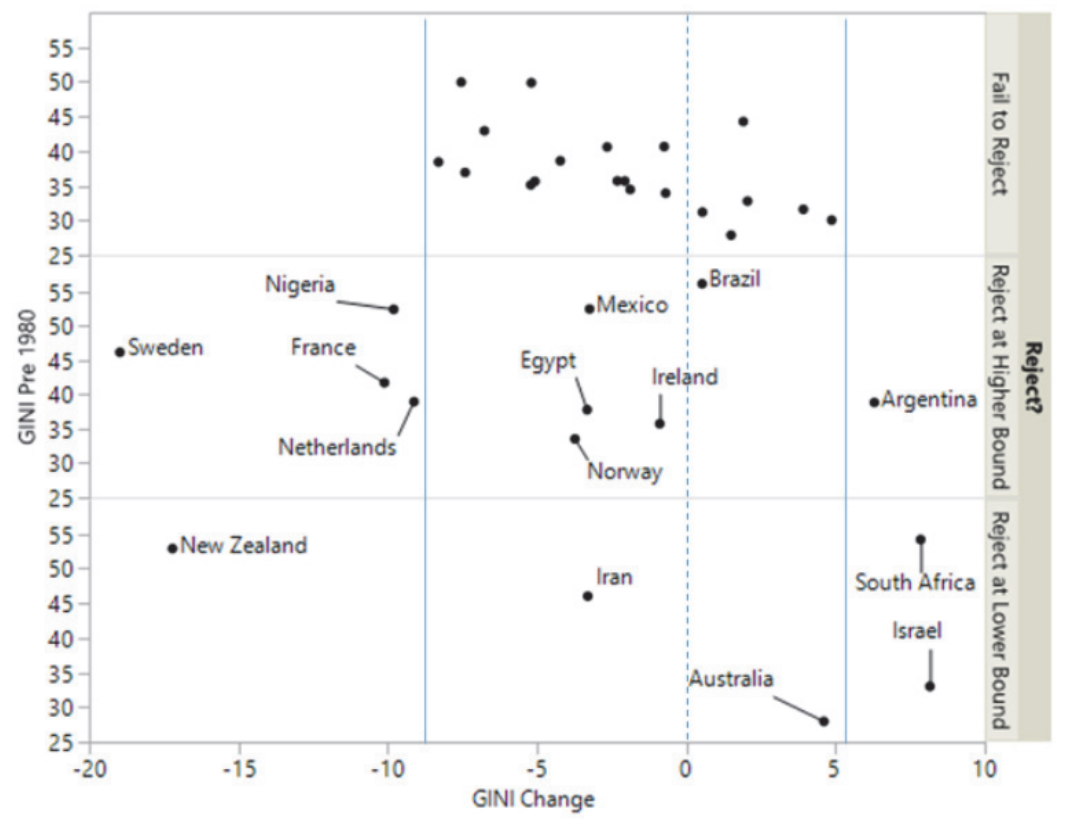

96 Journal of Applied Business and Economics Vol. 22(2) 2020 


\section{CONCLUDING REMARKS}

Both Marxist and Keynesian analyses of business cycles are grounded on under-consumption and fluctuations of aggregate demand while refuting Say's Law. While Marx's predicted the inevitability of the total collapse of capitalism, Keynes is credited for saving it. The major objective of the current research was to see how Marx's prediction have held up since the 1960s. We used GDP data from 35 countries to measure the extent of volatility of business cycles since the 1950s and how they correlate to inequality. The empirical deductions are mixed. While the depth of business cycles downturns was less severe in some countries during the post 1981 period, the opposite is apparent in about half of the countries scrutinized. To some extent, our results appear to confirm the evidence compiled by Jean Philippe Cotis and Jonathan Coppel (2005) use data from OECD countries to provide some insight about the dynamics of business cycles in OECD countries. They suggest that strong policy actions appear to have "extinguished" the business cycle while sustaining above average trend growth. For 1970-2003, they report an average of five business cycles with an average duration of 3.5 quarters. These authors attribute the U-shaped pattern of business cycles in European countries to robust automatic stabilizers. Economist Bill Conerly (2017) who studied the US business cycles from 1983 through 2007 concludes that business cycles moderated compared to earlier decades. He conjectures that the moderation in cyclicality of the US economy is mainly related to "improved inventory management, technological change, better execution of monetary policy, financial innovations, securitization and globalization".

While our empirical investigation supports some business cycle moderation, we cannot either confirm or falsify Marx's basic hypothesis about the future of capitalism. This warrants further investigation into the length of expansions and the degree of potential inequality generated at this time, as those at the lower end of the income distribution may be disproportionately affected once a recession starts. This is a topic of future work for us. Economic inequality has proved inexplicable in numerous resource rich countries in the Middle East, Africa and South America.

We note a concern exists for policy makers. Many countries have experienced an increase in inequality over the past 20 years, including some advanced economies in the West where the poor and middle class have suffered from stagnant wages and income. It is widely acquiesced that major economies of the West may be in danger of a serious recession when the middle and the lower stratum of society are unable to purchase and consume goods and services produced by the more affluent segment who own the means of production and distribution. Economics and political history make it profusely clear that economic insecurity and poverty which result from excessive inequality tend to spark unbearable suffering and hardship which typically incites social unrest, greater economic uncertainty and massive losses of wealth. Economic inequality and poverty force its victims to engage in destructive social activities such as theft, murder, uncontrollable black-market activities and destruction of public and private property. In addressing worsening poverty in the U.S., noted politicians and economists have advocated a guaranteed minimum income as an effective strategy to reduce income inequality and provide a social cushion for the U.S. underprivileged. Andrew Yang, a businessman and a candidate to become the next president of the United States, has proposed a universal basic income of $\$ 1,000$ a month for every American adult as a means to fight poverty and prevent of erosion of income due to job losses caused by automation. The issue of inequality in the presence of business cycles is important for policy makers looking to protect the poorest Americans and moderate future recessions. 


\section{REFERENCES}

Baumol, W. J. (1970). Mr. Harrod's model. Economic Dynamics ( ${ }^{\text {rd }}$ ed.). London: Macmillan, 37-55. Berger, M. (2016, August 30). Income and wealth inequality make recessions worse, research reveals. Retrieved from https://phys.org/news/2016-08-income-wealth-inequality-recessions-worse.html/.

Bernanke, B. S. (1945). The macroscopics of the Great Depression: A comparative approach. Journal of Money, Credit, and Banking, 27(1), 1-28.

Burns, A., \& Mitchel, W. (1947). Burns and Mitchell on business cycles. Journal of Political Economy, 55(4), 281-298.

Burns, A., \& Mitchell, W. (1946). Measuring Business Cycles. New York: National Bureau of Economic Research.

Cotis, J. P., \& Coppel, J. (2005, July 11-12). The Changing Nature of the Business Cycle. Reserve Bank of Australia Economic Conference, Sydney, Australia.

Conerly, B. (2017, September 25th). The Economic Futurist: Business Cycles -- How Frequent, How Severe? Forbes. Retrieved from https://www.forbes.com/sites/billconerly/2017/09/25/theeconomic-futurist-business-cycles-how-frequent-how-severe/\#7a8999f73339.

Federal Reserve Bank of St. Louis Economic Data [FRED]. (2019). Unemployment Rate. Retrieved from https://fred.stlouisfed.org/series/UNRATE.

Feenstra, R.C., Inklaar, R., \& Timmer, M. (2015). The Next Generation of the Penn World Table. American Economic Review, 105(10), 3150-3182. Retrieved from www.ggdc.net/pwt.

Friedman, M., \& Schwartz, A.J. (1963). A Monetary History of the United States, 1867-1960. Princeton: Princeton University Press for NBER.

Furman, J., \& Stiglitz, J. (1998). Economic consequences of income inequality. Proceedings - Economic Policy Symposium - Jackson Hole, Federal Reserve Bank of Kansas City, 221-263.

Galenson, W. \& Zellner, A. (1957). International comparison of unemployment rates. In UniversitiesNational Bureau (Ed.). The Measurement and Behavior of Unemployment (pp. 439-584). National Bureau of Economic Research.

Gertz, G., \& Kharas, H. (2019). Beyond Neoliberalism: Insights From Emerging Markets. Retrieved from https://www.brookings.edu/wp-content/uploads/2019/05/beyond-neoliberalism-final-05.01.pdf

Marx, K., \& Engels, F. (1930). The Manifesto of the Communist Party. London: Martin Lawrence Ltd. Original work published 1888.

Marx, K. (1976). The poverty of philosophy. In Marx-Engels Collected Works: Volume 6: Marx and Engels, 1845-1848. New York: International Publishers, 109-230. Original work published 1847.

Granados, J., \& Roux, A. (2009). Life and death during the Great Depression. Proceedings of the National Academy of Sciences, 106(41), 17290-17295.

Hahnel, R., \& Sherman, H.J. (1982). Income distribution and the business cycle: Three conflicting hypotheses. Journal of Economic Issues, 16(1), 49-73.

Harrod, R. F. (1939). An essay in dynamic theory. The Economic Journal, 49(193), 14-33.

Hashemzadeh, N., \& Farhat, D. (2017). Keynes' unscientific theory of the consumption function and its false policy implication for the multiplier effect: A review of disaggregated evidence. Journal of Economics and Public Finance, 3(2), 225-238.

Keynes, J. M. (1936). The General Theory of Employment, Interest and Money. London: Macmillan.

Lear, W.V. (1992). Income distribution and business cycles. Review of Social Economy, 50(3), 316-332.

National Bureau of Economic Research [NBER]. (2019). U.S. Business Cycle Expansions and Contractions. Retrieved from https://www.nber.org/cycles.html.

Piketty, T. (2014). Capital in the Twenty-First Century. Cambridge, MA: Belknap Press of Harvard University Press.

Pizzigati, S. (2018, February $8^{\text {th }}$ ). Inequality Was Responsible for the Depth of the Great Recession. Institute for Policy Studies. Retrieved from https://ips-dc.org/inequality-responsible-depth-greatrecession/. 
Piketty, T., \& Zucman, G. (2014). Capital is back: Wealth-income ratios in rich countries 1700-2010. The Quarterly Journal of Economics, 129(3), 1255-1310.

Romer, C. D. (1994). Business cycles. In The Library of Economics and Liberty. Retrieved from https://www.econlib.org/library/Enc/BusinessCycles.html.

Romer, C. D. (1994). Remeasuring business cycles. Journal of Economic History, 54(3), 573-609.

Romer, C. D. (1999). Changes in business cycles: Evidence and explanations. Journal of Economic Perspectives, 13(2), 23-44.

Romer, C. D. (2008). Business cycles. In D.R. Henderson (Ed.). The Concise Encyclopedia of Economics. Indianapolis: Liberty Fund.

Sewell, R., \& Booth, A. (2017). Understanding Marx's Capital: A Readers' Guide (2 ${ }^{\text {nd }}$ ed.). London: Wellred.

Sherman, H. (2004). The 2004 Veblen-Commons Award Recipient”, Journal of Economic Issues, 38(2), 311-314.

Sweezy, P. (1942). The Theory of Capitalist Development. New York: Monthly Review Press.

Vernon, J. R. (1994). Unemployment rates in postbellum America: 1869-1899. Journal of Macroeconomics, 16(4), 701-714.

World Inequality Database. (2019). Income and Wealth Inequality, USA, 1963-2014. Retrieved from https://wid.world/country/usa/.

\section{APPENDIX}

\section{TABLE 1}

GINI DATA AVAILABILITY FROM THE WORLD INCOME INEQUALITY DATABASE

\begin{tabular}{|c|c|c|}
\hline Country & Years Pre 1980 & Years Post 1980 \\
\hline Argentina & $\begin{array}{l}\text { 1953, 1959, 1961, 1963, 1965, 1965, } \\
1969-1970,1972,1974-1979\end{array}$ & 1980-1983, 1985-2017 \\
\hline Australia & 1950-1979 & 1980-2004, 2008, 2010-2012, 2014 \\
\hline Austria & 1970, 1972, 1976, 1977 & $\begin{array}{l}1981,1983,1987,1991,1994-2001,2003- \\
2016\end{array}$ \\
\hline Belgium & $1969,1973,1975-1977,1979$ & $1985,1988,1992-2001,2003-2016$ \\
\hline Brazil & $\begin{array}{l}\text { 1958, 1960, 1970, 1972, 1974, 1976, } \\
\text { 1978-1979 }\end{array}$ & $\begin{array}{l}\text { 1981-1990, 1992-1993, 1995-1999, 2001- } \\
2009,2011-2016\end{array}$ \\
\hline Canada & $\begin{array}{l}\text { 1951, 1957, 1961, 1965, 1967, 1969, } \\
1971,1973-1979\end{array}$ & $1980-2016$ \\
\hline Denmark & $\begin{array}{l}\text { 1952-1953, 1955, 1961, 1963, 1964, } \\
1966,1968,1971,1976,1978-1979\end{array}$ & 1980-2017 \\
\hline Egypt & $1958-1959,1965,1975$ & $\begin{array}{l}\text { 1981, 1991, 1996-1997, 2000, 2005, 2008- } \\
2013,2015\end{array}$ \\
\hline Finland & $1952,1962,1966,1971,1976-1977$ & $1981,1985-2017$ \\
\hline France & $1956,1962,1965,1970,1975,1978-1979$ & 1984, 1989-1990, 1994-2016 \\
\hline Germany & $\begin{array}{l}1950,1955,1960,1962,1964,1967- \\
1970,1973-1975,1978\end{array}$ & 1980-1981, 1983-2016 \\
\hline Greece & 1957-1971, 1974 & 1981, 1986, 1988, 1994-2001, 2003-2016 \\
\hline Hong Kong & $1957,1963,1966,1971,1973,1976$ & $\begin{array}{l}\text { 1980-1981, 1986, 1991, 1996, 2001, 2006, } \\
\text { 2011, } 2016\end{array}$ \\
\hline Iceland & NA & $2003-2016$ \\
\hline India & 1951-1970, 1973-1975, 1977 & 1983, 1986-1997, 1999, 2005, 2010, 2012 \\
\hline
\end{tabular}




\begin{tabular}{|c|c|c|}
\hline Country & Years Pre 1980 & Years Post 1980 \\
\hline Iran & $1959,1968-1974$ & $\begin{array}{l}\text { 1984, 1986, 1990, 1994, 1998, 2005-2006, } \\
\text { 2009, 2013-2014 }\end{array}$ \\
\hline Ireland & 1973 & $1980,1987,1994-2001,2003-2016$ \\
\hline Israel & $\begin{array}{l}\text { 1950, 1954, 1957-1958, 1961, 1963, } \\
1969,1976,1979\end{array}$ & $\begin{array}{l}1985-1987,1990,1992,1995,1997,2000- \\
2001,2005,2007-2016\end{array}$ \\
\hline Italy & $1967-1979$ & $\begin{array}{l}\text { 1980-1982, 1984, 1986-1987, 1989, 1991, } \\
1993,1995-2016\end{array}$ \\
\hline Japan & $1954,1956,1959,1962-1965,1967-1979$ & $\begin{array}{l}\text { 1980-1986, 1989-1990, 1992-1993, 1995, } \\
\text { 1997-1998, 2000, 2003-2004, 2006, 2008- } \\
\text { 2009, } 2012\end{array}$ \\
\hline Malaysia & 1958, 1960, 1968, 1970, 1976, 1979 & $\begin{array}{l}\text { 1984, 1987, 1989-1990, 1992, 1995, } 1997, \\
1999,2004,2007,2009,2011-2014,2016\end{array}$ \\
\hline Mexico & $\begin{array}{l}\text { 1950, 1956-1958, 1963, 1968-1970, } \\
1975,1977\end{array}$ & $\begin{array}{l}\text { 1984, 1989, 1992, 1994, 1996, 1998, } \\
\text { 2000, 2002, 2004-2006, 2008, 2010, 2012, } \\
\text { 2014, } 2016\end{array}$ \\
\hline Netherlands & $1950,1952,1962,1967,1973,1977$ & $1981,1983,1985,1987-2016$ \\
\hline $\begin{array}{l}\text { New } \\
\text { Zealand }\end{array}$ & 1954-1961, 1963-1978 & $\begin{array}{l}\text { 1980, 1982-1987, 1989-1992, 1995-1998, } \\
\text { 2000-2001, 2003-2004, 2007-2014 }\end{array}$ \\
\hline Niger & 1960 & $1993,1995,2005,2008,2011,2014$ \\
\hline Nigeria & $1959,1970-1972,1975$ & $\begin{array}{l}\text { 1980-1982, 1985-1986, 1992, 1996-1997, } \\
2004,2010\end{array}$ \\
\hline Norway & $1957,1960,1970,1973,1976,1979$ & $1982,1984-2016$ \\
\hline Portugal & 1973 & 1980, 1990-1991, 1995-2001, 2003-2016 \\
\hline $\begin{array}{l}\text { South } \\
\text { Africa }\end{array}$ & 1959-1960, 1965, 1970, 1975 & $\begin{array}{l}\text { 1980, 1985, 1987, 1990-1991, 1993, } 1995- \\
1997,2000-2001,2005,2008-2012,2015\end{array}$ \\
\hline $\begin{array}{l}\text { South } \\
\text { Korea }\end{array}$ & 1953, 1961, 1964-1966, 1968-1972, 1976 & $\begin{array}{l}\text { 1980, 1982, 1984-1985, 1988, 1992-1993, } \\
1995-1998,2004,2006-2015\end{array}$ \\
\hline Spain & 1965,1973 & $1980,1985-1990,1994-2016$ \\
\hline Sweden & 1951-1979 & $1980-2016$ \\
\hline Switzerland & 1978 & $\begin{array}{l}\text { 1982, 1991-1992, 1998, 2000-2002, 2004, } \\
2006-2016\end{array}$ \\
\hline Turkey & $1952,1963,1968,1973-1974,1978-1979$ & $1983,1987,1994,2002-2016$ \\
\hline $\begin{array}{l}\text { United } \\
\text { Kingdom }\end{array}$ & $1954-1955,1960-1979$ & $1980-2016$ \\
\hline $\begin{array}{l}\text { United } \\
\text { States }\end{array}$ & $1950-1952,1954-1979$ & $1980-2016$ \\
\hline
\end{tabular}

